\title{
Investigating the Perception of Students Regarding M- Learning Concept in Egyptian Schools
}

\author{
https://doi.org/10.3991/ijim.v11i6.7361 \\ Reham Adel Ali $\left.{ }^{\square}\right)$, Muhammad Rafie Mohd Arshad \\ Universiti Sains Malaysia (USM), Penang, Malaysia \\ reham_akwah@yahoo.com
}

\begin{abstract}
The Egyptian school education system is currently in a miserable state and facing some problems. To overcome the problems, there is a suggestion towards the development and implementation of mobile learning (mLearning) as a new learning tool in the education system. The aim of this paper is to investigate the Egyptian students' perception towards m-learning as a new learning tool and its benefits through a survey of 120 students from a public preparatory school in Egypt. Data was gathered and analyzed using Statistical Package for Social Science (SPSS) Version 23. The results demonstrated a positive attitude from the participants towards the benefits of M-learning. The majority of students showed their concerns about technical issues of m-learning such as the small screen and limited storage. The results also revealed the positive attitude towards the value of M-learning, especially for those who use Elearning resources. A large proportion of participants use their devices for different activities such as messages, Internet browsing and games rather than learning. This has point the need for more investigation to determine the factors that may affect the students' intention to use their devices in learning.
\end{abstract}

Keywords-M-learning, perception, education, Egypt, survey.

\section{Introduction}

In the light of diffusion of mobile devices and wireless networks, a new educational method has arisen in the form of mobile learning (m-Learning). M-learning will evolve the learning process from teacher-centered classroom with paper-based learning to student-centered learning with a more diverse learning environment to support and personalize lifelong and informal learning [1].

Mobile learning carries the meaning of learning at anytime and anywhere through the use of mobile devices and the wireless Internet [2]. In other words, mobile learning is known to overcome the challenge of learning locality through the feature of learners' mobility which is the fundamental characteristic of m-learning[3]. Mlearning applications (apps) are a common form of m-learning in the environment of education. These are small programs that are downloaded on a mobile device or accessed through wireless network. They allow the access to remote learning resources, educational games and quizzes. Additionally, they allow for communication among 
learners to share educational information [4]. Mobile learning is accomplished by the use of mobile devices such PDAs, Smartphones, Ipads and tablets. These devices are characterized by its small size and portability. According to Ally [5] some countries around the world are realizing the significance of mobile learning in education process and has started initiatives to implement the use of tablet computers and smart phones in schools.

Although literature focuses on the technical aspects and development of the mlearning applications, there is a need for studies that investigate the students' perception and readiness in developing countries towards the use of m-learning. Accordingly, the main focus of this paper is to investigate the Egyptian students' perception towards m-learning as a new learning tool and its benefits, and whether or not they agree that it is an efficient learning process. Additionally, this study will contribute to successfully adopting m-learning in Egypt in the future.

\section{$2 \quad$ Literature Review}

Mobile learning introduces new pedagogies and styles of learning, enabling education within the real contexts such as applications that allow students to capture and organize information that occur in specific places[3]. Hence, m-learning encourages lifelong and informal learning. Through mobile learning, students can learn with each other and they can be a source of knowledge or create their own content in contrast to traditional pedagogical models based on knowledge that are transferred from teachers to students without any participation from the students [3]. M-learning causes students to be the centre of the learning process and have more authority in their learning process. This will allow students to watch videos or listen to audio tracks then answer questions through their mobile devices[6]. As mobile device is an individual device, a sense of responsibility and self-managing of learning is supported by using $\mathrm{m}$ learning. Additionally, m-learning can support the concept of interaction and collaboration. Learners can better understand and apply concepts through knowledge sharing with their peers through many applications such as SMS, Whatsapp, viber, etc. Mobility feature is considered the distinctive feature for m-learning against traditional learning $[7,8]$. Mobility means learners can learn and exchange information anytime and anywhere.

Through the population of more than 88 million, Egypt has one of the biggest fixed-line and Internet markets in Africa and the Arab region. Mobile diffusion has reached $110 \%$ by mid-2016, and there is also a big mobile market[9]. According to UNCTAD [10] the number of people accessing the Internet using a mobile or a USB modem increased from around 7 million at the end of 2009 to 8.6 million at the end of December 2010. Internet penetration is also rising. Between 2006 and December 2010, it increased from 13.7 to 25.4 users per 100 inhabitants.

According to Galal [11], the educational system in Egypt is in a miserable state. The country ranked 139th out of 140 countries in the "quality of the education system" index in the World Economic Forum's 2015-2016 Global Competitiveness Report. The educational system has been criticized due to the strictness of the curricu- 
lum, dependence on rote memorization instead of scientific research, classroom overcrowding, limited availability of classrooms, lack of laboratories, and lack of competent teachers. School drop-outs, particularly among females, is to avoid the costs for transportation. Additionally, the teaching quality is poor and carries the style of transferring the knowledge to the students without any participation from them.

According to Sureephong, et al. [1], m-learning is a solution tool that changed the traditional teaching to modern teaching. Furthermore, Mobile learning represents a way to address a number of educational problems [12]. Accordingly, m-learning aims to be a new learning tool that may help to overcome the issues that exist in the Egyptian education system. Through mobility features, the problem of crowded classrooms and transportation problems may be solved. M-learning can support the concept of interactivity. An interaction happens among students themselves and between teachers and students through chats, SMS and e-mails breaks the routine in the traditional education system and the collaboration in learning that results from these interactions. In addition, m-learning has the ability to make the learning process enjoyable and interesting to relieve stress and anxiety of the study through edutainment solutions that are applied on mobile devices such as education games and E-books. Mobile learning allows the opportunity for the learners to be more personalized and selfdirected. Researchers stress the importance of allowing learners to exercise more control over their own learning instead of traditional pedagogical models based on the teacher transferring knowledge to learners without any participation from the students [13-15].

A study by GSMA and DOCOMO (2013) depicts the status of children in Egypt with a mobile device. The study was conducted among 1,030 pairs of children and guardians living across 12 geographic locations in Egypt. The age of the participating children was between eight and eighteen years old. The study revealed that $91 \%$ of children own a mobile device and $68 \%$ of children use their mobile device for calls and messages.. In addition, $94 \%$ of children access the Internet by their Smartphones. The study indicates that, $69 \%$ of children download or use entertainment applications and only $32 \%$ of children use their mobile devises for education and learning apps. Furthermore, $47 \%$ of children access social networking and micro-blogging sites on their devices. The study detects that $78 \%$ of parents showed concerns about the privacy of children when using their mobile devices and $65 \%$ of parents have introduced rules when their children use their devices. Majority of children agree on having a mobile device increases their confidence. Previous results indicate that children in Egypt are familiar with mobile devices and agree that using mobile devises increase their self-confidence. Hence applying mobile learning in Egypt may progress the education system. One of the priorities to successfully adopt m-learning technology in Egypt is to understand the users' perception about the technology used. Hence, this study aims to investigate the Egyptian students' perception towards m-learning as a new learning tool, and its benefits. 


\section{$3 \quad$ Methodology}

\subsection{Participants}

The purpose of this study is to investigate the Egyptian students' perception towards $\mathrm{m}$-learning as a new learning tool and its benefits. The study was conducted among120 students from a public preparatory school in Egypt, Cairo. The participants were 9 th grade students. A total of 120 students were given the questionnaire and all of them returned the completed questionnaire. Paper based survey questionnaires were used to collect the data. Demographic information of the students is shown in Table 1.

\subsection{Research Instrument}

A questionnaire was prepared to investigate the students' perception towards $\mathrm{m}$ learning as a new learning tool and its benefits. Students were requested to fill the questionnaire, which include several kinds of questions. Firstly, a five-point Likert scale consisting of 10 statements was designed to determine the students' attitude towards m-learning (e.g. "I believe that using m-learning will increase the flexibility to learn."). Similar studies used this Likert scale to assess attitudes and perceptions of the respondents towards m-learning [16, 17]. Secondly, closed format questions (5 questions) were applied, (e.g. "Did you hear about m-learning before?"). Previous studies have used this type of question format to determine the awareness of mobile learning, mobile devices usage and the availability of mobile devices[18].

Cronbach alpha is a statistical analysis measure used to calculate the coefficient for internal consistency reliability for any scales. In general, the accepted lower limit for Cronbach alpha is 0.70 (DeVellis, 2003) which is regarded as the acceptable reliability coefficient. The results of the reliability analysis are given in Table 2 . The questionnaire is a reliable measurement instrument.

Table 1. Profile of respondents

\begin{tabular}{|c|c|c|}
\hline Profile & Frequency & Percentage \\
\hline Gender & & \\
Male & 81 & 67.5 \\
Female & 39 & 32.5 \\
\hline Age & & \\
$11-13$ & 45 & 37.5 \\
$14-16$ & 75 & 62.5 \\
\hline Own Smartphone & 34 & 28.3 \\
Own tablet & 35 & 29.2 \\
Own both & 51 & 42.5 \\
\hline
\end{tabular}

Table 2. Reliability of Measurements

\begin{tabular}{|c|c|c|}
\hline Factor & Number of items & Cronbach's Alpha \\
\hline M-learning benefits & 6 & 0.852 \\
\hline M-learning difficulties & 4 & 0.746 \\
\hline
\end{tabular}




\section{$4 \quad$ Results}

This study used Statistical Package for Social Science (SPSS) Version 23 to code and analyze the gathered data.

\subsection{Results from Likert scale questions}

The data collected from the respondents are displayed in Table 3 which explains the percentages of the descriptive statistics for the students' perception towards the benefits of m-learning and students' perception of the difficulties of m-learning which was measured by a Likert scale. The five level of Likert items consists of strongly disagree, disagree, undecided, agree and strongly agree and was ranked from "strongly agree" (5) to "strongly disagree"(1) [19].

Table 3. Descriptive Statistics for the Questionnaire Indicators.

\begin{tabular}{|c|c|c|c|c|c|c|c|}
\hline Statement & $\begin{array}{c}\text { Strongly } \\
\text { Agree }\end{array}$ & Agree & $\begin{array}{c}\text { undecid- } \\
\text { ed }\end{array}$ & $\begin{array}{l}\text { Disa- } \\
\text { gree }\end{array}$ & $\begin{array}{l}\text { Strongly } \\
\text { Disagree }\end{array}$ & $\begin{array}{l}\text { Not } \\
\text { respond- } \\
\text { ed }\end{array}$ & Total \\
\hline \multicolumn{8}{|c|}{ M-learning benefits } \\
\hline $\begin{array}{l}\text { Q1. I believe that using m- } \\
\text { learning will increase the flexibil- } \\
\text { ity to learn. }\end{array}$ & $\begin{array}{c}63 \\
(52.5 \%)\end{array}$ & $\begin{array}{c}26 \\
(21.7 \%)\end{array}$ & $\begin{array}{c}19 \\
(15.8 \%)\end{array}$ & $\begin{array}{c}3 \\
(2.5 \%)\end{array}$ & $\begin{array}{c}9 \\
(7.5 \%)\end{array}$ & $\begin{array}{c}0 \\
(0 \%)\end{array}$ & $\begin{array}{c}120 \\
100 \%\end{array}$ \\
\hline $\begin{array}{l}\text { Q2. I believe using m-Learning } \\
\text { will make the educational process } \\
\text { more enjoyable. }\end{array}$ & $\begin{array}{c}23 \\
(19.2 \%)\end{array}$ & $\begin{array}{c}75 \\
(62.5 \%)\end{array}$ & $\begin{array}{c}10 \\
(8.3 \%)\end{array}$ & $\begin{array}{c}8 \\
(6.7 \%)\end{array}$ & $\begin{array}{c}0 \\
(0 \%)\end{array}$ & $\begin{array}{c}4 \\
(3.3 \%)\end{array}$ & $\begin{array}{c}120 \\
100 \%\end{array}$ \\
\hline $\begin{array}{l}\text { Q3. I think that using m-learning } \\
\text { will help me to get good grades. }\end{array}$ & $\begin{array}{c}38 \\
(31.7 \%)\end{array}$ & $\begin{array}{c}53 \\
(44.2 \%)\end{array}$ & $\begin{array}{c}20 \\
(16.7 \%)\end{array}$ & $\begin{array}{c}7 \\
(5.8 \%)\end{array}$ & $\begin{array}{c}1 \\
(0.8 \%)\end{array}$ & $\begin{array}{c}1 \\
(0.8 \%)\end{array}$ & $\begin{array}{c}120 \\
100 \%\end{array}$ \\
\hline $\begin{array}{l}\text { Q4. I believe that implementing } \\
\text { m-Learning in the educational } \\
\text { process will increase communica- } \\
\text { tion between teachers and stu- } \\
\text { dents }\end{array}$ & $\begin{array}{c}32 \\
(26.7 \%)\end{array}$ & $\begin{array}{c}55 \\
(45.8 \%)\end{array}$ & $\begin{array}{c}21 \\
(17.5 \%)\end{array}$ & $\begin{array}{c}5 \\
(4.2 \%)\end{array}$ & $\begin{array}{c}7 \\
(5.8 \%)\end{array}$ & $\begin{array}{c}0 \\
(0 \%)\end{array}$ & $\begin{array}{c}120 \\
100 \%\end{array}$ \\
\hline $\begin{array}{l}\text { Q5. Implementing m-Learning } \\
\text { will enable me to have independ- } \\
\text { ent learning. }\end{array}$ & $\begin{array}{c}30 \\
(25.0 \%)\end{array}$ & $\begin{array}{c}72 \\
(60.0 \%)\end{array}$ & $\begin{array}{c}9 \\
(7.5 \%)\end{array}$ & $\begin{array}{c}8 \\
(6.7 \%)\end{array}$ & $\begin{array}{c}0 \\
(0 \%)\end{array}$ & $\begin{array}{c}1 \\
(0.8 \%)\end{array}$ & $\begin{array}{c}120 \\
100 \%\end{array}$ \\
\hline $\begin{array}{l}\text { Q6. Mobile learning promote and } \\
\text { increase the knowledge }\end{array}$ & $\begin{array}{c}29 \\
(24.2 \%)\end{array}$ & $\begin{array}{c}50 \\
(41.7 \%)\end{array}$ & $\begin{array}{c}29 \\
(24.2 \%)\end{array}$ & $\begin{array}{c}9 \\
(7.5 \%)\end{array}$ & $\begin{array}{l}3 \\
(2.5 \%)\end{array}$ & $\begin{array}{c}0 \\
(0 \%)\end{array}$ & $\begin{array}{c}120 \\
100 \%\end{array}$ \\
\hline \multicolumn{8}{|c|}{ M-learning difficulties } \\
\hline $\begin{array}{l}\text { Q7. carrying laptops is an obsta- } \\
\text { cle in the mobile learning }\end{array}$ & $\begin{array}{c}54 \\
(45.0 \%) \\
\end{array}$ & $\begin{array}{c}25 \\
(20.8 \%) \\
\end{array}$ & $\begin{array}{c}28 \\
(23.3 \%) \\
\end{array}$ & $\begin{array}{c}11 \\
(9.2 \%) \\
\end{array}$ & $\begin{array}{c}2 \\
(1.7) \\
\end{array}$ & $\begin{array}{c}0 \\
(0 \%) \\
\end{array}$ & $\begin{array}{c}120 \\
100 \%\end{array}$ \\
\hline $\begin{array}{l}\text { Q8. Small screens phones and } \\
\text { tablet is an obstacle in the mobile } \\
\text { learning }\end{array}$ & $\begin{array}{c}34 \\
(28.3 \%)\end{array}$ & $\begin{array}{c}29 \\
(24.2 \%)\end{array}$ & $\begin{array}{c}49 \\
(40.8 \%)\end{array}$ & $\begin{array}{c}8 \\
(6.7 \%)\end{array}$ & $\begin{array}{c}0 \\
(0 \%)\end{array}$ & $\begin{array}{c}0 \\
(0 \%)\end{array}$ & $\begin{array}{c}120 \\
100 \%\end{array}$ \\
\hline $\begin{array}{l}\text { Q9. Limited storage capacity for } \\
\text { mobile devices is an obstacle in } \\
\text { the mobile learning. }\end{array}$ & $\begin{array}{c}37 \\
(30.8 \%)\end{array}$ & $\begin{array}{c}48 \\
(40.0 \%)\end{array}$ & $\begin{array}{c}21 \\
(17.5 \%)\end{array}$ & $\begin{array}{c}10 \\
(8.3 \%)\end{array}$ & $\begin{array}{c}3 \\
(2.5 \%)\end{array}$ & $\begin{array}{c}1 \\
(0.8 \%)\end{array}$ & $\begin{array}{c}120 \\
100 \%\end{array}$ \\
\hline $\begin{array}{l}\text { Q10. Batteries must be charged } \\
\text { regularly is an obstacle in the } \\
\text { mobile learning. }\end{array}$ & $\begin{array}{c}65 \\
(54.2 \%)\end{array}$ & $\begin{array}{c}24 \\
(20.0 \%)\end{array}$ & $\begin{array}{c}16 \\
(13.3 \%)\end{array}$ & $\begin{array}{c}9 \\
(7.5 \%)\end{array}$ & $\begin{array}{c}6 \\
(5.0 \%)\end{array}$ & $\begin{array}{c}0 \\
(0 \%)\end{array}$ & $\begin{array}{c}120 \\
100 \%\end{array}$ \\
\hline
\end{tabular}


Table 4 displays the standard deviation of the acquired data. The standard deviation is a statistical measure that explains how the data disperse around the mean. A large standard deviation indicates the data further from the mean and shows that there is a lot of variation in the answers. A smaller standard deviation indicates that the data are similar and more of the data is close to the mean. According to [20] when all responses to questions are the same, a standard deviation obtained is 0 . The standard deviations of the questions in Table 4.2 ranges between 0.75 and 1.20 , indicating that students' answers are similar. The standard deviations of the questions in Table 4 ranges between 0.75 and 1.20 , indicating that students' answers are similar.

Table 4. Mean and Standard Deviation of the Questionnaire Indicators

\begin{tabular}{|c|c|c|c|c|}
\hline \multirow{2}{*}{ Statement } & \multicolumn{2}{|c|}{$\mathbf{N}$} & \multirow{2}{*}{ Mean } & \multirow{2}{*}{ Std. Deviation } \\
\hline & Valid & Missing & & \\
\hline \multicolumn{5}{|c|}{ M-learning benefits } \\
\hline $\begin{array}{l}\text { Q1. I believe that using m-learning } \\
\text { will increase the flexibility to learn. }\end{array}$ & 120 & 0 & 4.09 & 1.209 \\
\hline $\begin{array}{l}\text { Q2. I believe using m-Learning will } \\
\text { make the educational process more } \\
\text { enjoyable. }\end{array}$ & 116 & 4 & 3.97 & 0.751 \\
\hline $\begin{array}{l}\text { Q3. I think that using m-learning will } \\
\text { help me to get good grades. }\end{array}$ & 119 & 1 & 4.01 & 0.897 \\
\hline $\begin{array}{l}\text { Q4. I believe that implementing m- } \\
\text { Learning in the educational process } \\
\text { will increase communication between } \\
\text { teachers and students }\end{array}$ & 120 & 0 & 3.83 & 1.056 \\
\hline $\begin{array}{l}\text { Q5. Implementing m-learning will } \\
\text { enable me to have independent learn- } \\
\text { ing. }\end{array}$ & 119 & 1 & 4.04 & 0.775 \\
\hline $\begin{array}{l}\text { Q6. Mobile learning promote and } \\
\text { increase the knowledge }\end{array}$ & 120 & 0 & 3.78 & 0.983 \\
\hline \multicolumn{5}{|c|}{ M-learning difficulties } \\
\hline $\begin{array}{l}\text { Q7. carrying laptops is an obstacle in } \\
\text { the mobile learning }\end{array}$ & 120 & 0 & 3.98 & 1.100 \\
\hline $\begin{array}{l}\text { Q8. Small screens phones and tablet is } \\
\text { an obstacle in the mobile learning }\end{array}$ & 120 & 0 & 3.74 & 0.948 \\
\hline $\begin{array}{l}\text { Q9. Limited storage capacity for } \\
\text { mobile devices is an obstacle in the } \\
\text { mobile learning. }\end{array}$ & 119 & 1 & 3.89 & 1.023 \\
\hline $\begin{array}{l}\text { Q10. Batteries must be charged regu- } \\
\text { larly is an obstacle in the mobile } \\
\text { learning. }\end{array}$ & 120 & 0 & 4.11 & 1.194 \\
\hline
\end{tabular}

To measure students' perception towards the benefits of using m-learning, five questions were prepared. In question one, when the students were asked if ('mlearning will increase the flexibility in the learning process'), most of the students agreed with mean 4.09. In the second question, the students were asked if ('m-learning would make the educational process more enjoyable'). The mean of the results was 3.97, which is nearly equals to agree. Another significant finding was that students 
agree that ('m-learning would help them to get good grades') with mean score 4.01. About the ('m-learning would increase the communication between teachers and students'), the mean score was 3.83, which indicates a positive response in this aspect. The mean score response for the fifth question was 4.04, which means the students agree on the ('m-learning enhance independent learning'). The next question was prepared to discover ('if students thought m-learning would promote and increase knowledge'). The mean score of the answers for this question was 3.78, which is near to 'Agree'.

The following four questions were prepared to gather information on the perception of the difficulties of m-learning for students. In question seven, when the students were asked ('if carrying laptops is an obstacle in mobile learning'). The mean of the results was 3.97, which is nearly equals to agree. Question eight was ('if small screen phones and tablet is an obstacle in the mobile learning'). The mean score was 3.74, which is close to 'Agree'. The mean score for the next question ('Limited storage capacity for mobile devices is an obstacle in the mobile learning') was 3.89, which is close to 'Agree'. The mean of the last question was 4.11, which is 'Agree' on ('the batteries are an obstacle in m-learning because they must be charged regularly').

\subsection{Results Obtained from Closed Format Questions}

Figure 1 shows that $28.3 \%$ of the respondents have a smartphone; $29.2 \%$ owned tablet PC; $42.5 \%$ owned both (smartphone and tablet). The study reveals that the participants use the E-learning platform in their learning with a high percentage (75\%) (Figure 2).

It is also worth mentioning that $83.3 \%$ of the students were aware of the $\mathrm{m}$ learning concept, while $14.2 \%$ of them have not heard about it (Figure 3). Furthermore, fig. 3 shows that $58.3 \%$ of the students believed that $\mathrm{m}$-learning is ('a good idea and they would like to use it'), while $30.8 \%$ consider ('it is a good idea but they would not like to use it'). Only $9.2 \%$ of the students ('do not think it is a good idea').

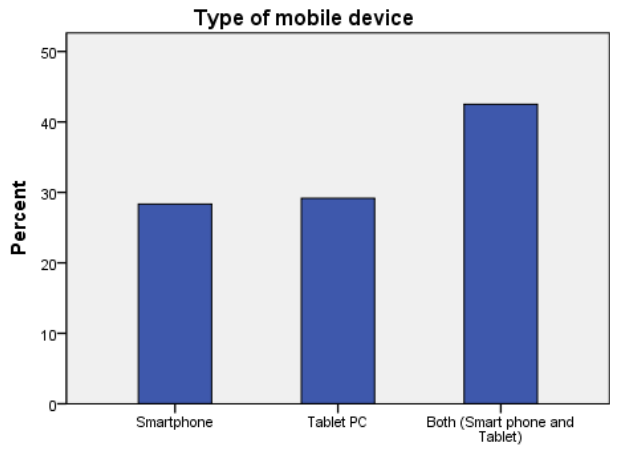

Fig. 1. Students' Availability of Mobile Devices

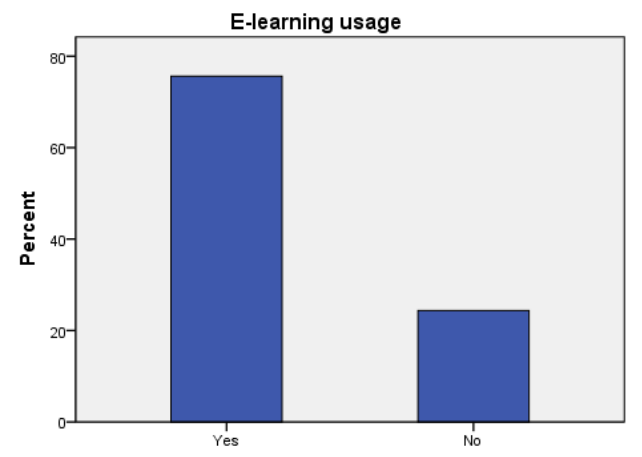

Fig. 2. E-learning Usage 


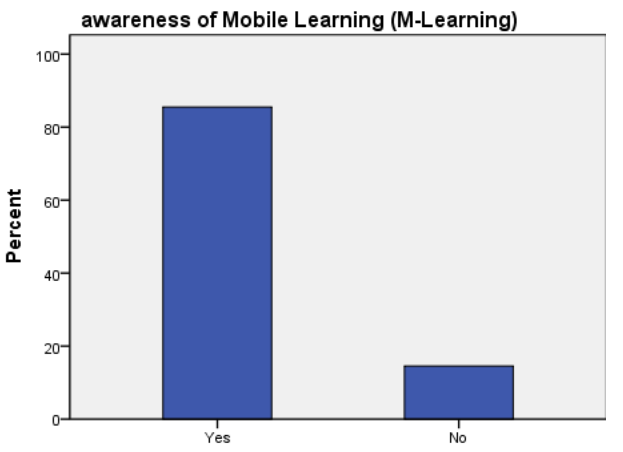

Fig. 3. Awareness of M-learning

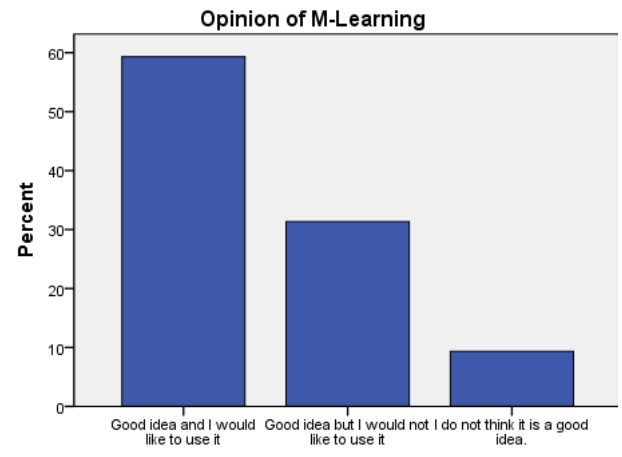

Fig. 4. Students' Opinion about M-learning

About the purpose of using mobile devices, table 5 shows the purpose of using mobile devices for students and presents the frequency and percentage for each purpose. Table 5 displays four categories of the purpose of mobile device usage; (i) Messages, (ii) Games and music, (iii) Internet and browsing and (iv) Learning. Based on Table 5, 66.7\% of the students used their devices for Internet and browsing. Additionally, there are only $26.5 \%$ of students who use their devices for learning.

Table 5. Purpose of Using Mobile Devices

\begin{tabular}{|l|c|c|}
\hline \multicolumn{1}{|c|}{ purpose } & frequency & percentage \\
\hline Messages & 58 & $49.6 \%$ \\
\hline Games and music & 70 & $59.8 \%$ \\
\hline Internet and browsing & 78 & $66.7 \%$ \\
\hline Learning & 31 & $26.5 \%$ \\
\hline
\end{tabular}

\section{Discussion}

Majority of the students agreed that m-learning will increase the flexibility in the learning process and make the learning process more enjoyment. M-learning promotes and increase their knowledge. Additionally, the communication between the students and their teachers become more effective by using m-learning. Most of the students agreed on the fact that m-learning will encourage a sense of responsibility and independent learning thus increasing their confidence and make them more active and involved in creating knowledge. These results are in line with [Al-Fahad [21], 22, 23]. In general, the study revealed the positive attitude towards the advantages of $\mathrm{m}$ learning. A high percentage of students showed their concerns about technical issues of m-learning such as the small screen size of the mobile devices, limited storage and charging the batteries regularly. These issues need to be deemed by the developers of m-learning applications. They must develop m-learning content that fits with different screen size of mobile devices. 
The results obtained from this study indicate that the majority of students own both (smartphone and tablet PCs). The results also show that there is a relation between who is already using E-learning resources in their studies and their opinion towards the importance of m-learning. More usage of E-learning leads to more positive attitudes towards using m-learning. In addition, the results revealed that the majority of students have heard about the concept of m-learning. Although a positive attitude towards the value of m-learning and the awareness of Egyptian students towards the m-learning concept, a high percentage of students use their mobile devices in different activities rather than learning purposes. These results are in line with GSMA and DOCOMO [24]. This issue needs to be considered by researchers to determine the factors that may affect the intention to use mobile devices for learning purposes.

\section{Conclusion}

In the light of diffusion of mobile devices and wireless networks, mobile technology has become an important tool in education. This study investigates the perception of 120 students from a public preparatory school in Egypt towards the employment of m-learning in their studies.

The study revealed positive attitude from the students to the advantages of $\mathrm{m}$ learning. The students supported the idea of utilizing m-learning in their studies because it helps them to access different resources anytime and anywhere in order to get knowledge so it increases the flexibility in learning.

M-learning promotes the communication between teachers and students. Further, the educational process becomes more enjoyable by using it. The results also revealed the students' concerns about the technical difficulties of mobile devices such as battery charging and small screen. Moreover, a high percentage of participants use their devices for different activities such as messages, Internet browsing and games rather than learning. Therefore, more effort is needed to determine the factors that affect the students' intention to use their devices in learning. In addition, the study found that using E-learning resources influence the students' perception towards the value of $\mathrm{m}$ learning. More usage of E-learning leads to more positive attitude towards using mlearning.

Overall, the study advocated to the adoption of mobile learning. Therefore, parents and teachers have to encourage their students to use their mobile devices in studying and learning. Moreover, the Ministry of Education has to take steps to adopt mobile learning in Egyptian schools so that the students can use the technology to learn and connect with the world anywhere and anytime.

\section{$7 \quad$ References}

[1] P. Sureephong, P. Sirichai, and S. Winya, "Technology Acceptance of Thai Primary Student on Outdoor Learning Activity Using Mobile Device," in Subconscious Learning via Games and Social Media, ed: Springer, 2015, pp. 101-113. 
Paper-Investigating the Perception of Students Regarding M-Learning Concept in Egyptian Schools

[2] R. A. Ali and M. R. M. Arshad, "Understanding intention to use mobile learning: a perspective of the extended unified theory of acceptance and use of technology," International Journal of ADVANCED AND APPLIED SCIENCES (IJAAS). 2016.

[3] R. A. Ali and M. R. M. Arshad, "Perspectives of Students' Behavior Towards Mobile Learning (M-learning) in Egypt: an Extension of the UTAUT Model," Engineering, Technology \& Applied Science Research, vol. 6, pp. pp. 1109-1114, 2016.

[4] D. Vogel, D. M. Kennedy, K. Kuan, R. Kwok, and J. Lai, "Do mobile device applications affect learning?," in System Sciences, 2007. HICSS 2007. 40th Annual Hawaii International Conference on, 2007, pp. 4-4. https://doi.org/10.1109/HICSS.2007.181

[5] M. Ally, "Mobile learning: from research to practice to Impact Education," Learning and Teaching in Higher Education: Gulf Perspectives, vol. 10, 2013.

[6] N. Gedik, A. Hanci-Karademirci, E. Kursun, and K. Cagiltay, "Key instructional design issues in a cellular phone-based mobile learning project," Computers \& Education, vol. 58, pp. 1149-1159, 2012. https://doi.org/10.1016/j.compedu.2011.12.002

[7] C. Coursaris and K. Hassanein, "Understanding m-commerce: a consumer-centric model," Quarterly journal of electronic commerce, vol. 3, pp. 247-272, 2002.

[8] Y. Liu, "Solving the puzzle of mobile learning adoption," PhD, Åbo Akademi University, 2011.

[9] H. Lancaster, "Egypt - Telecoms Infrastructure, Operators, Regulations - Statistics and Analyses," 2016.

[10] UNCTAD, "ICT POLICY REVIEW OF EGYPT," 2011.

[11] R. Galal. (2016, 2 June). How Egypt plans to build its next generation of scientists.

[12] D. M. West, "Mobile learning: Transforming education, engaging students, and improving outcomes," Center for Technology Innovation at Brookings. Mobile Learning, pp. 1-17, 2013.

[13] R. L. Donaldson, "Student acceptance of mobile learning," THE FLORIDA STATE UNIVERSITY, 2011.

[14] Y. Huang, "Empirical Analysis on Factors Impacting Mobile Learning Acceptance in Higher Engineering Education," PhD, The University of Tennessee, 2014.

[15] S.-S. Liaw, M. Hatala, and H.-M. Huang, "Investigating acceptance toward mobile learning to assist individual knowledge management: Based on activity theory approach," Computers \& Education, vol. 54, pp. 446-454, 2010. https://doi.org/10.1016/j.compedu. 2009.08.029

[16] S. M. Jacob and B. Issac, "The mobile devices and its mobile learning usage analysis," arXiv preprint arXiv:1410.4375, 2014.

[17] A. A. Amer and H. A. A. Hafez, "Mobile learning concepts and its effects on student's attitudes in Egypt," in Computer Engineering Conference (ICENCO), 2011 Seventh International, 2011, pp. 43-48.

[18] N. F. Taharim, A. M. Lokman, W. A. R. W. M. Isa, and N. L. M. Noor, "Investigating feasibility of mobile learning (M-learning) for history lesson," in International Colloquium of Art and Design Education Research (i-CADER 2014), 2015, pp. 541-550.

[19] A. Bryman, Social research methods: Oxford university press, 2015.

[20] J. Fielding and G. N. Gilbert, Understanding social statistics, 2nd ed.: Sage, 2006.

[21] F. N. Al-Fahad, "Students' attitudes and perceptions towards the effectiveness of mobile learning in King Saud University, Saudi Arabia," TOJET: The Turkish Online Journal of Educational Technology, vol. 8, 2009.

[22] I. Ismail, R. M. Idrus, A. A. Ziden, and M. Rosli, "Adoption of mobile learning among distance education students in Universiti Sains Malaysia," International Journal of Interactive Mobile Technologies (iJIM), vol. 4, pp. 24-28, 2010. 
[23] S. M. Jacob and B. Issac, "Mobile technologies and its impact-an analysis in higher education context," International Journal of Interactive Mobile Technologies, vol. 2, 2008.

[24] GSMA and N. DOCOMO, "Children's use of mobile - an international comparison 2013 (Survey Study)," 2013.

\section{Authors}

Reham Adel Ali (corresponding author) is a doctorate candidate at the School of Computer Sciences, Universiti Sains Malaysia (USM), Penang, Malaysia. She obtained her Master's Degree in Information systems from Cairo University, School of computers and informatics, Egypt in 2011. Her research interests include information systems, databases, mobile learning, E-learning and information systems acceptance models and theories.

Muhammad Rafie Mohd Arshad is an Associate Professor at the School of Computer Sciences, Universiti Sains Malaysia (USM), Penang, Malaysia, where he teaches Management of Information Systems, Multimedia Systems, E-Learning and Virtual Reality. His research interests include RFID Applications, Mobile Application for Hajj \& Umrah and IT management. He has various research and publications. (rafie@cs.usm.my).

Article submitted 28 June 2017. Published as resubmitted by the authors 13 August 2017. 